\title{
Influence of the Type of Silage in the Dairy Cow Ration, with or without Grazing, on the Fatty Acid and Antioxidant Profiles of Milk
}

\author{
Senén De La Torre-Santos, Luis J. Royo (D), Adela Martínez-Fernández (D), Mario Menéndez-Miranda, \\ Rocío Rosa-García and Fernando Vicente *D
}

check for

updates

Citation: De La Torre-Santos, S.;

Royo, L.J.; Martínez-Fernández, A.;

Menéndez-Miranda, M.; Rosa-García,

R.; Vicente, F. Influence of the Type of

Silage in the Dairy Cow Ration, with

or without Grazing, on the Fatty Acid

and Antioxidant Profiles of Milk.

Dairy 2021, 2, 716-728. https://

doi.org/10.3390/dairy2040055

Academic Editor: Burim Ametaj

Received: 30 July 2021

Accepted: 23 November 2021

Published: 10 December 2021

Publisher's Note: MDPI stays neutral with regard to jurisdictional claims in published maps and institutional affiliations.

Copyright: (c) 2021 by the authors. Licensee MDPI, Basel, Switzerland. This article is an open access article distributed under the terms and conditions of the Creative Commons Attribution (CC BY) license (https:// creativecommons.org/licenses/by/ $4.0 /)$.
Servicio Regional de Investigación y Desarrollo Agroalimentario (SERIDA), Carretera AS-267, PK. 19, 33300 Villaviciosa, Spain; senen_30@msn.com (S.D.L.T.-S.); ljroyo@serida.org (L.J.R.); admartinez@serida.org (A.M.-F.); mmiranda@serida.org (M.M.-M.); rociorosa@gmail.com (R.R.-G.)

* Correspondence: fvicente@serida.org

\begin{abstract}
Dairy systems based on grass and forages are widely spread throughout the European Atlantic Arc and they have an influence on milk quality. Likewise, legumes are a key element in the farms to improve cows' diet and farm feed self-sufficiency. The aim of this study was to evaluate the effect of the legumes in the diet and the feeding system (pasture-based vs. confined) on milk production and composition. An assay was performed with 18 Friesian cows randomized into two management groups (grazing or confined). Three total mixed rations based on Italian ryegrass, faba bean or field pea silages were offered ad libitum for nine continuously housed cows or during two hours after each milking for another nine grazing cows. Regardless of type of silage, grazing cows had higher dry matter intake and milk production than confined cows. Likewise, grazing cows produced milk with a lower concentration of protein and urea than confined cows. The dairy cows fed total mixed rations based on both legume silages had a milk fat with a higher proportion of unsaturated fatty acids, especially with the inclusion of faba bean silage in the diet. The results demonstrate that the profile of fatty acids and antioxidants is related to the feeding system in dairy cows. Grazing directly influenced the composition of milk, decreasing the proportion of saturated fatty acids and increasing the content of unsaturated fatty acids, as CLA, and the antioxidants, as lutein and $\beta$-cryptoxanthin.
\end{abstract}

Keywords: legume; grazing; fatty acids; antioxidants; milk

\section{Introduction}

The perspective of the consumer regarding food production and livestock has changed in the last few years. Nowadays, food safety and nutritional properties are not the only factors important to them. New key elements, such as sustainable food production, environmental impact, resilient livestock, animal welfare, etc., have become essential [1]. This complexity requires sustainability consideration as a social issue and demands integrated efforts by a wide range of stakeholders to capitalise on the strength of livestock production systems and minimize the potential negative impact of a rapid growth in demand and supply of animal products. It is also imperative that these efforts be realistic, equitable and aware of the ecological, socioeconomic and cultural dimensions [2], and generate added value in the market and are reflected in consumer health.

Pastures and forages represent a natural, sustainable, and economical way of feeding dairy cows from a nutritional point of view and the livestock profitability [3]. Forages are an important natural source of vitamins and fatty acids in ruminant diets, and their concentrations in forages species are important in determining their quantity and profile in milk and milk derivatives [4]. The protein is one of the most expensive components of dairy cow diets, with a high impact on the cost of milk production [5]. The dairy farmers 
must buy most of the protein sources of cow rations and depend on purchased soybean meal, which is predominantly produced overseas [6]. The high prices, traceability, and consumer concerns about deforestation for the cultivation of animal feed have caused an interest in cheaper and greener ways of producing local proteins [7]. Therefore, the farmer should reorganize their feed system by becoming self-sufficient in proteins and to reduce imported protein feeds for dairy cow rations [8]. Annual legume crops such as field pea, faba bean, or lupin used for silage are cheap sources of protein and starch for livestock and they can improve the production efficiency systems on dairy farms by reducing the need for concentrates $[9,10]$. The legumes bring numerous positive environmental effects, including nitrogen fixation in the soil, less use of mineral fertilisers and water, greater diversification in crop rotation, and an increase in the biodiversity. All this allows farmers to reduce production costs and protect the environment [11].

The faba bean (Vicia faba L.) has the highest average $\mathrm{N}_{2}$ fixation capacity $(200 \mathrm{~kg} / \mathrm{ha})$ of the main legumes, high dry matter production, high protein concentration, and high digestibility [12]. In addition, it has low buffer capacity and high content of water-soluble carbohydrates, which provide it with an acceptable silage [13]. The field pea (Pisum sativum L.) has higher protein content, lower neutral detergent fiber, and greater digestibility of organic matter than faba bean. However, though its buffer capacity is similar to faba bean, it has lower content of soluble sugars. Therefore, field pea has less substrate for microorganisms during lactic fermentation and, in consequence, lower ensilability than faba bean [14]. In general, the legumes have higher concentrations of total fatty acids than grasses, which can be transferred to milk [15]. The concentrations of antioxidants, such as tocopherols, carotenes and lutein, in forage are affected by forage species and their phenological stage [16]. However, the secretion of antioxidants to milk seems limited in amount [17].

The objective of this study was to evaluate the role of feed composition (legume addition to the diet) and feeding system (pasture based versus confined) on the production and composition of milk, specially focused on milk fatty acid and antioxidant concentrations.

\section{Materials and Methods}

\subsection{Experimental Design and Treatments}

The study was carried out at the SERIDA experimental farm $\left(43^{\circ} 28^{\prime} 20^{\prime \prime} \mathrm{N}, 5^{\circ} 26^{\prime} 10^{\prime \prime} \mathrm{W}\right.$; $10 \mathrm{~m}$ above sea level). Eighteen Holstein dairy cows in the second half of lactation were selected with an initial average weight of $645 \pm 79 \mathrm{~kg}$ (average \pm standard error), $2.2 \pm 1.5$ lactations, $89 \pm 40$ days in milk and an average daily production of $30.6 \pm 4.3 \mathrm{~kg}$ of milk. The cows were randomly distributed into two groups of nine cows and each one assigned to two feeding managements (grazing or confined). Both groups were subdivided into three subgroups of three cows each one in order to evaluate three total mixed ration (TMR) based on silages (Italian ryegrass, faba bean, and field pea) in three consecutive periods. Both TMR were isoenergetic and isonitrogenous and formulated according to NRC [18], and were prepared daily in a mixed wagon. The ingredient composition of total mixed rations is detailed in Table 1. Each period lasted 19 days, including 13 days of changeover and six days of sampling and measurements. The experimental treatments were: (1) TMR based on Italian ryegrass silage in housing (IR); (2) TMR based on faba bean silage in housing (FB); (3) TMR based on field pea silage in housing (FP); (4) TMR based on grazing plus Italian ryegrass silage (IR $+G) ;(5)$ TMR based on grazing plus Italian faba bean silage $(F B+G)$, and $(6)$ TMR based on grazing plus field pea silage $(F P+G)$. 
Table 1. Ingredient composition (\% dry matter basis) of the total mixed rations based on Italian ryegrass silage (IR), faba bean silage (FB), and field pea silage (FP).

\begin{tabular}{|c|c|c|c|}
\hline Ingredient & IR & FB & FP \\
\hline Maize silage & 51.1 & 41.7 & 44.2 \\
\hline Italian ryegrass silage & 19.0 & -1 & - \\
\hline Faba bean silage & - & 28.6 & - \\
\hline Fied pea silage & - & - & 25.3 \\
\hline Barley straw & 4.0 & 3.7 & 3.9 \\
\hline Rapeseed meal & 12.2 & 7.8 & 5.4 \\
\hline Compound feedstuff 2 & 13.7 & 18.1 & 21.2 \\
\hline
\end{tabular}

${ }^{1}$ Not included; ${ }^{2}$ Ingredients in descending order of the percentages by weight present in the compound feedstuff: cornflakes, corn, soybean meal, barley, sunflower meal, rye, by-pass fat, soybean hulls, calcium carbonate, sodium bicarbonate, cottonseed, sugarbeet pulp, sodium chloride, dicalcium phosphate.

\subsection{Experimental Procedure}

The total mixed rations were offered ad libitum to dairy cows in confined group, and during two hours after each milking session to grazing group. The animals of grazing group were moved to a grazing plot for the rest of day. The experimental grazing area comprised of 10.5 ha divided into seven paddocks with a wide range of grasses: Agrostis sp. (51.64\%), Lolium perenne L. (9.78\%), Poa sp. (8.15\%), Bromus sp. (6.23\%), Dactylis glomerata L. $(1.00 \%)$, legumes: Trifolium repens L. $(0.98 \%)$, and other species: Cerastium arvense $(5.36 \%)$, Taraxacum sp. (5.10\%), Malva sp. (5.06\%), Ranunculus sp. (4.54\%), Sonchus sp. (3.57\%), Bellis sp. (1.84\%), and Veronica chamaedrys L. (0.81\%). No grass was in bloom. The rotation interval was approximately 6 days, with nine rotations over the duration of this study. All treatments were supplemented daily with $2.66 \mathrm{~kg}$ of concentrate (dry matter basis) offered during milking sessions. Water was always available.

The individual intake of the silage treatments was automatically recorded daily by an electronic weighing system integrated with a scale pen by a computerized system. Herbage intakes on pasture were estimated using the animal performance method [19]. Briefly, the energy requirements were considered as those net energy requirements for maintenance, lactation, body weight changes, walking, and grazing. The net energy from herbage intake was estimated as the total energy requirements minus the net energy supplied by concentrate intake. Concentrate intake was recorded daily by an automatic feeder coupled to the milking system. All cows were milked twice daily (at 7:00 and 19:00 h). Milk production was measured in both milking sessions.

\subsection{Sampling and Chemical Analyses}

Herbage in the grazing treatment was sampled three times for each sampling period on alternate days by the hand plucking method to estimate diet selection, food intake, and diet quality by simulation of the observed diet in the cows. In addition, the grazing plot was sampled the previous day of the data collection period by tracing a diagonal transect across the available grazing area to measure the herbage availability. The grass sample consisted of a sampling area of $1 \mathrm{~m}^{2}$ per hectare composed by five subsamples of the forage cut at $6 \mathrm{~cm}$ of height over a surface of $2 \times 0.1 \mathrm{~m}$ with a hand mower. Five grass height measurements were recorded before harvesting on each cut strip. After grazing, postgrazing sward heights were also recorded as described previously. Samples of concentrate were taken at the beginning of each experimental period. Total mixed rations were sampled daily during the experimental period and pooled in one sample by period.

Herbage and total mixed ration samples were dried at $60^{\circ} \mathrm{C}$ for $24 \mathrm{~h}$ to determine the dry matter content, and ground at $0.75 \mathrm{~mm}$. Concentrate samples were milled at $1.00 \mathrm{~mm}$. Feed samples were analyzed for organic matter $(\mathrm{OM})$, crude protein $(\mathrm{CP})$, starch, neutral detergent fiber (NDF), and acid detergent fiber (ADF) by near infrared spectroscopy (FOSS NIRSystem 5000, Silver Springs, MD, USA). The energy content was estimated according to NRC [18]. The extraction and methylation of the fatty acids (FA) were carried out simultaneously [20]. The esterification of FA was performed using a toluene and methanolic 
hydrochloric acid solution as follows: heating at $70{ }^{\circ} \mathrm{C}$ in a water bath for $2 \mathrm{~h}$, cooling at room temperature and adding $2 \mathrm{~mL}$ of hexane and $5 \mathrm{~mL}$ of $\mathrm{K}_{2} \mathrm{CO}_{3}(6 \% w / v)$ and centrifuging for $5 \mathrm{~min}$ at $2500 \mathrm{rpm}$. The organic phase was immediately evaporated in a nitrogen stream to obtain an oily residue and dissolved in $0.8 \mathrm{~mL}$ of hexane. FA methyl esters were separated, identified, and quantified using TRACE GC Ultra equipment (Thermo Fisher Scientific, Waltham, MA, USA) with flame ionization detector (FID), using a $100 \mathrm{~m} \times 0.25 \mathrm{~mm}$ i.d. fused silica capillary column (SP-2560 Capillary GC Column, Sigma-Aldrich Inc., Saint Louis, MO, USA). Helium was used as carrier gas at a flow rate of $0.6 \mathrm{~mL} / \mathrm{min}$. The temperature of the injector and detector were 250 and $260{ }^{\circ} \mathrm{C}$, respectively. The injection volume was $1 \mu \mathrm{L}$. The initial column temperature was set at $140{ }^{\circ} \mathrm{C}$ for $5 \mathrm{~min}$; from 140 to $200{ }^{\circ} \mathrm{C}$ at $3{ }^{\circ} \mathrm{C} / \mathrm{min}$ and held for $5 \mathrm{~min}$; from 200 to $240{ }^{\circ} \mathrm{C}$ at $3{ }^{\circ} \mathrm{C} / \mathrm{min}$ and held for $5 \mathrm{~min}$ and, finally, held for $38 \mathrm{~min}$. Individual FA were quantified through internal calibration using methylated 9:0, 17:1, 19:0 and 20:2 fatty acids as internal standards. The samples for antioxidant assay were immediately vacuum packed and frozen $\left(-20^{\circ} \mathrm{C}\right)$ and analyzed [21]. The samples were treated with liquid nitrogen in a Robot Coupe R6 grinder (Vincennes, France). The processing of samples was performed in dim light, using opaque glass. Butylhydroxytoluene $(0.1 \% v / v)$ was added as antioxidant, $\mathrm{NaHCO}_{3}$ as neutralizing agent, and $10 \mathrm{ppm}$ of echinenone and $3 \mathrm{ppm}$ of $\delta$-tocopherol as internal standards. The lipophilic components were extracted by washing three times with acetone. The analytes were extracted with petroleum ether, the organic phase was evaporated under a nitrogen stream and the dry residue was saponified with $\mathrm{KOH}$ in $\mathrm{MeOH}(5.5 \%$ w/v) for $15 \mathrm{~min}$ at room temperature. After centrifugation at $1000 \times g$ for $5 \mathrm{~min}$ at room temperature, the organic phase was collected, evaporated again, and reconstituted in the mobile phase. Finally, it was filtered through a syringe filter (Acrodisc Syringe Filter GHP, $25 \mathrm{~mm}, 0.2 \mu \mathrm{m}$, Waters, MA, USA) and transferred into a high-performance liquid chromatography (HPLC) vial. An HPLC (Alliance 2695, Waters, MA, USA) system equipped with two serial detectors, UV-Vis and fluorescence, was used for the simultaneous detection and separation of xanthophylls, carotenes, and vitamins A and $\mathrm{E}$. The separation of antioxidant was carried out using a reverse phase column RP C18 Kinetex $2.6 \mu \mathrm{m} 4.6 \times 150 \mathrm{~mm}$ (Phenomenex, Torrance, CA, USA). The sample and column were kept refrigerated at 10 and $13^{\circ} \mathrm{C}$, respectively. The elution of the components in the column was performed using a flow of $0.6 \mathrm{~mL} / \mathrm{min}$ and a quaternary gradient of mobile phase. The quantification was carried out using external calibration models, quantifying the fat-soluble antioxidants according to the recovery factor of both internal standards.

Samples of milk were taken during both milking sessions on the second, fourth and sixth days of the data collection period. Both daily samples from each cow were mixed proportionally according to the milk produced in each milking sessions. The sample of the first day was added with azidiol for macronutrients analyses. The second and third samples were immediately frozen $\left(-20^{\circ} \mathrm{C}\right)$ until fatty acid and antioxidant analyses, respectively.

Milk samples were analyzed for fat, protein, lactose, non-fat solids, and urea by MilkoScan FT6000 (FOSS, Hilleroed, Denmark). Fatty acids were analyzed according to standard methods ISO14156:2001/IDF172 for lipids extraction and ISO15884:2002/IDF182 for preparation on fatty acid methyl esters. Twenty milliliters of milk were mixed with $96 \%$ ethanol, 30\% ammonia solution, and diethyl ether. After shaking for $1 \mathrm{~min}$, the mixture was left to stand to achieve separation phase, then hexane was added, mixed carefully, and left to stand for a second phase separation. Finally, the aqueous layer was discarded. Sodium sulfate solution $(10 \% w / v)$ was added to the remaining content, mixed carefully again, left to stand for a third phase separation and, thereafter, the aqueous layer was discarded. The organic layer was transferred to a conical flask, mixed with anhydrous sodium sulfate, left to stand for $10 \mathrm{~min}$ and filtered. Finally, the filtrate was evaporated in a rotary steamer (Buchi R-114, Flawil, Switzerland) under a nitrogen stream in a water bath set at $50{ }^{\circ} \mathrm{C}$. The extract was dissolved in hexane, saponified as described above, and $0.5 \mathrm{~g}$ of sodium hydrogen sulfate were added. Finally, it was centrifuged at $1000 \times g$ for $5 \mathrm{~min}$ at room temperature. FA methyl esters were separated, identified, and quantified using a Varian 
3900 GC (Varian Inc., Palo Alto, CA, USA) with a flame ionization detector (FID), using a $120 \mathrm{~m} \times 0.25 \mathrm{~mm}$ i.d. capillary column (BPX70 GC column, Thermo Fisher Scientific, Waltham, MA, USA). Helium was used as carrier gas at a flow rate of $1.3 \mathrm{~mL} / \mathrm{min}$. The temperature of the injector and detector were $250^{\circ} \mathrm{C}$. The initial column temperature was $45^{\circ} \mathrm{C}$ for $5 \mathrm{~min}$; from 45 to $175^{\circ} \mathrm{C}$ at $13{ }^{\circ} \mathrm{C} / \mathrm{min}$ and held for $27 \mathrm{~min}$; from 175 to $215^{\circ} \mathrm{C}$ at $4{ }^{\circ} \mathrm{C} / \mathrm{min}$ and held for $35 \mathrm{~min}$. The individual FA peaks were identified by comparison of their retention times with those of pure methyl ester standards (Supelco 37 Component FAME Mix and TVA methyl standard of Supelco Inc., Saint Louis, MO, USA, and methyl CLAc9t11 of Matreya LCC., State College, PA, USA). Individual FA were quantified using an internal calibration using methylated 9:0, 17:1c10, 18:2c12t10 (Matreya LCC., State College, PA, USA) and 19:0 (Sigma-Aldrich, Saint Louis, MO, USA). Milk samples were thawed the day before antioxidants analysis and tempered before simultaneous extraction of carotenoids and vitamins [22]. The identification and quantification of antioxidants were carried out according to the methodology described for the analysis of foods antioxidants.

\subsection{Statistical Analysis}

Statistical analysis was performed using the $\mathrm{R}$ statistical package [23]. Each cow fed a given treatment at each period was considered the experimental unit in all analyses. Dry matter intake, milk yield and milk composition were analyzed by an analysis of variance according to a mixed model: $Y_{i j k}=m+M_{i}+S_{j}+P_{k}+(M \times S)_{i j}+C_{1}+e_{i j k l}$, where $Y_{i j k}$ was the dependent variable, $m$ the overall mean, $M_{i}$ the management (confined or grazing), $S_{j}$ the type of TMR (based on Italian ryegrass, faba bean or field pea silages), $C_{1}$ the animal effect, and $\mathrm{e}_{\mathrm{ijk} \mathrm{k}}$ the residual error. Management, TMR, and period were considered as fixed effects, and cow as the random effect. Significance was set at $p<0.05$. When the ANOVA was significant, means were separated by Tukey's test pairwise comparison.

\section{Results}

Table 2 shows the nutritive value of the total mixed rations made from silages of Italian ryegrass (IR), faba bean (FB), and field pea (FP), fresh forage used in grazing treatments and concentrate used in all treatments. The majority of the fatty acids (FA) present in the total mixed rations, fresh forage, and concentrate were palmitic acid (16:0), oleic acid (18:1 cis-9), linoleic acid (18:2 cis-9, cis-12), and linolenic acid (18:3 cis-9, cis-12, cis-15), amounting to $93.00 ; 92.08 ; 91.57 ; 87.48$, and $94.94 \%$, for IR, FB, FP, herbage and concentrate, respectively. About $50 \%$ of the FA of the fresh forage was in the form of linolenic acid. The mean values in vitamins $\mathrm{E}$ and carotenoids (xanthophylls and carotenes) of the feed samples are shown too. The lutein was the main antioxidant in total mixed rations and herbage while the concentrate only had significant amounts of tocopherol.

Table 2. Chemical composition (dry matter (DM) basis), net energy, fatty acid and antioxidant profiles of total mixed rations based on Italian ryegrass silage (IR), faba bean silage (FB), and field pea silage $(\mathrm{FP})$, and fresh forage used in grazing group and concentrate offered during milking.

\begin{tabular}{lccccc}
\hline Component & IR & FB & FP & Herbage & Concentrate \\
\hline Dry Matter (DM, \%) & 36.06 & 40.63 & 38.86 & 16.17 & 87.66 \\
Organic Matter (\% DM) & 90.51 & 89.86 & 88.43 & 90.52 & 92.24 \\
Crude Protein (\% DM) & 14.62 & 14.51 & 15.63 & 18.60 & 22.55 \\
Starch (\% DM) & 17.42 & 18.76 & 19.50 & ND & 37.65 \\
Neutral Detergent Fiber (\% DM) & 42.40 & 41.53 & 37.63 & 44.04 & 20.22 \\
Acid Detergent Fiber (\% DM) & 26.81 & 24.96 & 23.75 & 21.6 & 8.37 \\
Net Energy of lactation (Mcal/kg DM) & 1.56 & 1.57 & 1.57 & 1.62 & 1.96 \\
Fatty Acids (g/100 g fatty acids) & & & & & \\
10:1 cis-9 & 0.03 & 0.04 & 0.02 & 0.28 & 0.02 \\
11:0 & 0.11 & 0.40 & 1.04 & 0.21 & 0.01 \\
12:0 & 0.31 & 0.27 & 0.29 & 0.70 & 0.18 \\
13:0 & 0.25 & 0.18 & 0.20 & 0.86 & 0.01 \\
$14: 0$ & 0.48 & 0.47 & 0.51 & 0.62 & 0.49 \\
$15: 0$ & 0.09 & 0.10 & 0.11 & 0.14 & 0.05 \\
$15: 1$ cis-10 & 0.33 & 0.23 & 0.28 & 1.33 & 0.00 \\
\hline
\end{tabular}


Table 2. Cont.

\begin{tabular}{|c|c|c|c|c|c|}
\hline Component & IR & FB & FP & Herbage & Concentrate \\
\hline $16: 0$ & 16.91 & 17.79 & 19.29 & 18.19 & 25.33 \\
\hline $16: 1$ cis $-7+16: 1$ trans- 9 & 0.48 & 0.47 & 0.46 & 2.31 & 0.05 \\
\hline $16: 1$ cis-9 & 0.48 & 0.43 & 0.41 & 0.27 & 0.14 \\
\hline $17: 0$ & 0.18 & 0.19 & 0.18 & 0.28 & 0.10 \\
\hline 18:0 & 1.95 & 2.16 & 2.38 & 1.98 & 2.77 \\
\hline $18: 1$ cis-9 & 22.32 & 21.80 & 21.89 & 3.74 & 28.09 \\
\hline $18: 2$ cis- 9 cis -12 & 38.05 & 39.94 & 40.32 & 16.50 & 39.15 \\
\hline $18: 3$ cis- 6 cis- 9 cis- 12 & 0.06 & 0.13 & 0.11 & 0.11 & 0.05 \\
\hline $18: 3$ cis- 9 cis- 12 cis -15 & 15.72 & 12.55 & 10.07 & 49.05 & 2.37 \\
\hline 20:0 & 0.50 & 0.57 & 0.60 & 0.73 & 0.29 \\
\hline $20: 1$ cis -9 & 0.44 & 0.87 & 0.08 & 0.24 & 0.25 \\
\hline $20: 1$ cis -11 & 0.22 & 0.23 & 0.51 & 0.31 & 0.35 \\
\hline $21: 0$ & 0.10 & 0.11 & 0.13 & 0.17 & 0.05 \\
\hline $22: 0$ & 0.48 & 0.48 & 0.50 & 1.08 & 0.13 \\
\hline 23:0 & 0.09 & 0.10 & 0.13 & 0.15 & 0.03 \\
\hline $24: 0$ & 0.38 & 0.41 & 0.44 & 0.65 & 0.09 \\
\hline $24: 1$ & 0.06 & 0.09 & 0.06 & 0.11 & 0.01 \\
\hline$\sum$ SFA $^{1}$ & 21.82 & 23.23 & 25.79 & 25.75 & 29.52 \\
\hline$\sum$ MUFA $^{2}$ & 24.36 & 24.15 & 23.71 & 8.58 & 28.91 \\
\hline$\sum$ PUFA $^{3}$ & 53.83 & 52.61 & 50.50 & 65.67 & 41.56 \\
\hline PUFA:SFA ratio & 2.47 & 2.27 & 1.96 & 2.55 & 1.41 \\
\hline n6:n3 ratio & 2.42 & 3.18 & 4.00 & 0.34 & $\begin{array}{l}1.71 \\
16.54\end{array}$ \\
\hline \multicolumn{6}{|l|}{ Antioxidants (mg/kg DM) } \\
\hline Neoxanthin & 0.99 & 0.7 & 0.61 & 14.97 & 0.04 \\
\hline Violaxanthin & 0.39 & 0.31 & 0.46 & 13.28 & $<\mathrm{LQ}^{5}$ \\
\hline Antheraxanthin & 1.05 & 0.76 & 0.66 & 1.58 & 0.01 \\
\hline Lutein & 25.83 & 16.4 & 20.49 & 62.45 & 0.43 \\
\hline Zeaxanthin & 2.07 & 1.51 & 2.82 & 3.21 & 0.07 \\
\hline B-Criptoxanthin & 0.10 & 0.10 & 0.10 & 0.57 & 0.04 \\
\hline$\sum$-trans- $\beta$-Carotenes & 5.28 & 3.15 & 2.4 & 30.81 & 0.09 \\
\hline 9-cis- $\beta$-Carotenes & 1.76 & 1.1 & 0.5 & 6.28 & 0.06 \\
\hline 13 -cis- $\beta$-Carotenes & 0.60 & 0.44 & 0.34 & 3.44 & 0.08 \\
\hline$\alpha$-tocopherol & 7.22 & 6.91 & 7.11 & 9.64 & 2.83 \\
\hline$\gamma$-tocopherol & 3.46 & 3.34 & 2.83 & 1.60 & 4.29 \\
\hline
\end{tabular}

${ }^{1}$ SFA: saturated fatty acids; ${ }^{2}$ MUFA: monounsaturated fatty acids; ${ }^{3}$ PUFA: polyunsaturated fatty acids; ${ }^{4}$ ND: non-determined; ${ }^{5}<$ LQ: below quantification level.

The dry matter intake, milk production and composition of milk by the cows fed the experimental treatments, grazing and non-grazing, are presented in Table 3. Dry matter (DM) intake of total mixed rations was similar among indoor treatments $(19.57 \mathrm{~kg}$ DM per day) and among grazing treatments (9.53 kg of DM per day). The concentrate intake during milking sessions was higher $(p<0.05)$ in the confined cows than in the grazing cows, and in the outdoors treatments, a higher intake was observed in the grazing cows fed with FP ration compared to the other two rations. The average of grazing allotments were $39.7 \mathrm{~kg} \mathrm{DM} / \mathrm{cow}$ and day, and all paddocks were grazed to a post-grazing height over $6 \mathrm{~cm}$. The daily intake of fresh forage in grazing treatments was higher $(p<0.001)$ with the FB ration than with the IR and FP rations. The total dry matter intake was greater $(p<0.01)$ in grazing cows than housing animals, regardless of the type of total mixed ration. The forage:concentrate ratio was 80:20 for confined treatments and 82:18 for grazing treatments. Total daily milk production and fat content were not affected by the different treatments, although they tended $(p<0.1)$ to be higher with grazing $(30.1 \mathrm{~kg} /$ day $)$ than with the confined management $(28.2 \mathrm{~kg} /$ day). However, protein and urea content were lower $(p<0.001)$ in the grazing management. Similarly, with the inclusion of legumes silage, protein concentration decreased $(p<0.01)$ and urea increased $(p<0.001)$ in milk, especially in confined animals and with FP treatment in both managements. The somatic cell counts in the milk were higher in the samples from grazing cows compared to the indoor ones $(p<0.05)$. 
Table 3. Food intake (kg DM/d), milk yield (kg/d) and milk composition (g/kg) according to the type of silage (D) included in the total mixed rations based on Italian ryegrass silage (IR), faba bean silage (FB), and field pea silage (FP), with or without grazing $(G)$.

\begin{tabular}{|c|c|c|c|c|c|c|c|c|c|c|}
\hline Component & IR & FB & FP & $\mathrm{IR}+\mathrm{G}$ & $\mathrm{FB}+\mathrm{G}$ & $\mathbf{F P}+\mathrm{G}$ & SD & D & G & $\mathbf{D} * \mathbf{G}$ \\
\hline Total mixed ration & $18.65^{a}$ & $19.94^{\mathrm{a}}$ & $20.12^{a}$ & $9.24^{b}$ & $9.48^{b}$ & $9.88^{b}$ & 4.321 & 0.000 & 0.000 & 0.928 \\
\hline Concentrate & $2.78^{\mathrm{a}}$ & $2.82^{\mathrm{a}}$ & $2.80^{\mathrm{a}}$ & $2.59^{\mathrm{c}}$ & $2.60^{c}$ & $2.68^{b}$ & 0.074 & 0.000 & 0.000 & 0.195 \\
\hline Herbage & 0.00 & 0.00 & 0.00 & $12.17^{b}$ & $16.24^{\mathrm{a}}$ & $10.47^{\mathrm{b}}$ & 4.205 & 0.000 & $\mathrm{NA}^{4}$ & NA \\
\hline Total DMI ${ }^{1}$ & $21.43^{b}$ & $22.76^{\mathrm{ab}}$ & $22.92^{a b}$ & $24.00^{a b}$ & $28.32^{\mathrm{a}}$ & $23.04^{a b}$ & 5.714 & 0.187 & 0.084 & 0.367 \\
\hline $\operatorname{Milk}(\mathrm{kg} / \mathrm{d})$ & 28.25 & 28.46 & 27.91 & 30.15 & 30.13 & 30.10 & 4.156 & 0.706 & 0.096 & 0.983 \\
\hline Fat $(\mathrm{g} / \mathrm{kg})$ & 4.14 & 4.36 & 4.31 & 4.14 & 4.07 & 4.17 & 0.383 & 0.564 & 0.177 & 0.512 \\
\hline Protein $(\mathrm{g} / \mathrm{kg})$ & $3.76^{\mathrm{a}}$ & $3.63^{a b}$ & $3.61^{a b c}$ & $3.52^{b c}$ & $3.46^{\mathrm{c}}$ & $3.54 \mathrm{bc}$ & 0.156 & 0.004 & 0.001 & 0.280 \\
\hline Lactose $(\mathrm{g} / \mathrm{kg})$ & 4.75 & 4.74 & 4.78 & 4.78 & 4.83 & 4.76 & 0.142 & 0.784 & 0.389 & 0.480 \\
\hline $\mathrm{NFS}^{2}(\mathrm{~g} / \mathrm{kg})$ & $9.32^{\mathrm{a}}$ & $9.16^{\mathrm{ab}}$ & $9.17^{\mathrm{ab}}$ & $9.07^{b}$ & $9.06^{\mathrm{b}}$ & $9.07^{b}$ & 0.176 & 0.025 & 0.003 & 0.397 \\
\hline Urea (mg/kg) & 253 & $272 \mathrm{bc}$ & $325^{a}$ & $234^{d}$ & $238^{\mathrm{cd}}$ & $278^{b}$ & 33.4 & 0.000 & 0.000 & 0.474 \\
\hline $\operatorname{SCC}^{3}(\times 1000 / \mathrm{mL})$ & 40 & 66 & 42 & 138 & 173 & 196 & 194.2 & 0.357 & 0.028 & 0.898 \\
\hline
\end{tabular}

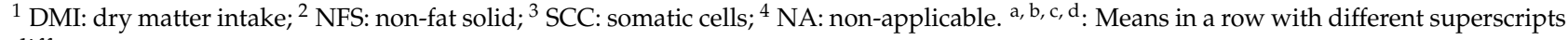
differ among treatments.

Table 4 shows the milk fatty acid profile from cows feeding the different total mixed rations and with two types of management. Significant changes related to the dry matter intake and management were observed. The concentration of monounsaturated fatty acids (MUFA), polyunsaturated fatty acids (PUFA), and total CLA differed between both treatments $(p<0.001)$. They were higher in both total mixed rations based on legumes than in based on ryegrass and they were also higher in the grazing treatments than in the indoor ones.

Table 4. Fatty Acid Profile (g/100 g fatty acids) of milk according to the type of silage (D) included in the total mixed rations based on Italian ryegrass silage (IR), faba bean silage (FB), and field pea silage (FP), with or without grazing (G).

\begin{tabular}{|c|c|c|c|c|c|c|c|c|c|c|}
\hline Fatty Acid & IR & FB & $\mathbf{F P}$ & $\mathrm{IR}+\mathrm{G}$ & $F B+G$ & $F P+G$ & SD & $\mathrm{D}$ & $\mathrm{G}$ & $\mathbf{D} * \mathbf{G}$ \\
\hline $4: 0$ & $5.08^{a}$ & $5.23^{a}$ & $5.31^{\mathrm{a}}$ & $4.57^{\mathrm{ab}}$ & $4.33^{\mathrm{b}}$ & $4.17^{\mathrm{ab}}$ & 0.381 & 0.056 & 0.004 & 0.678 \\
\hline $6: 0$ & $2.44^{\mathrm{ab}}$ & $2.41^{\mathrm{ab}}$ & $2.48^{\mathrm{a}}$ & $2.22^{b c}$ & $2.13^{c}$ & $2.22^{b c}$ & 0.125 & 0.028 & 0.001 & 0.926 \\
\hline $8: 0$ & $1.30^{\mathrm{a}}$ & $1.23^{a b}$ & $1.28^{\mathrm{ab}}$ & $1.22 \mathrm{ab}$ & $1.18^{\mathrm{b}}$ & $1.19^{b}$ & 0.050 & 0.093 & 0.011 & 0.818 \\
\hline 10:0 & 3.16 & 2.87 & 2.93 & 3.03 & 2.88 & 2.92 & 0.184 & 0.417 & 0.619 & 0.766 \\
\hline $10: 1$ cis-9 & 0.46 & 0.41 & 0.46 & 0.40 & 0.43 & 0.41 & 0.035 & 0.220 & 0.067 & 0.201 \\
\hline $11: 0$ & 0.10 & 0.08 & 0.08 & 0.09 & 0.07 & 0.07 & 0.016 & 0.323 & 0.545 & 0.989 \\
\hline $12: 0$ & 3.94 & 3.41 & 3.58 & 3.76 & 3.58 & 3.62 & 0.279 & 0.328 & 0.817 & 0.546 \\
\hline $12: 0$ iso & 0.14 & 0.11 & 0.12 & 0.12 & 0.12 & 0.11 & 0.020 & 0.658 & 0.529 & 0.498 \\
\hline 12:0 anteiso & $0.03^{b}$ & $0.04^{b}$ & $0.04^{b}$ & $0.05^{\mathrm{a}}$ & $0.05^{\mathrm{a}}$ & $0.05^{\mathrm{a}}$ & 0.004 & 0.000 & 0.000 & 0.141 \\
\hline $12: 1$ & 0.18 & 0.15 & 0.16 & 0.17 & 0.17 & 0.16 & 0.022 & 0.812 & 0.865 & 0.538 \\
\hline 13:0 & 0.16 & 0.14 & 0.13 & 0.14 & 0.13 & 0.13 & 0.023 & 0.706 & 0.431 & 0.929 \\
\hline $13: 0$ iso & $0.17^{a b c}$ & $0.20^{a b}$ & $0.21^{\mathrm{a}}$ & $0.15^{c}$ & $0.17^{b c}$ & $0.16^{b c}$ & 0.018 & 0.038 & 0.005 & 0.602 \\
\hline $14: 0$ & 12.11 & 11.48 & 11.55 & 11.82 & 12.01 & 12.08 & 0.549 & 0.609 & 0.347 & 0.365 \\
\hline $14: 0$ iso & $0.27^{b}$ & $0.29^{b}$ & $0.27^{\mathrm{b}}$ & $0.33^{a}$ & $0.34^{\mathrm{a}}$ & $0.33^{\mathrm{a}}$ & 0.019 & 0.001 & 0.000 & 0.788 \\
\hline $14: 1$ cis-9 & 1.29 & 1.13 & 1.23 & 1.11 & 1.21 & 1.16 & 0.109 & 0.390 & 0.275 & 0.171 \\
\hline $14: 0$ anteiso & $0.59^{b}$ & $0.62^{b}$ & $0.59^{b}$ & $0.72^{\mathrm{a}}$ & $0.73^{\mathrm{a}}$ & $0.70^{\mathrm{a}}$ & 0.042 & 0.003 & 0.000 & 0.888 \\
\hline $15: 0$ & 1.23 & 1.17 & 1.16 & 1.19 & 1.17 & 1.16 & 0.097 & 0.957 & 0.785 & 0.917 \\
\hline $15: 0$ iso & $0.39^{b}$ & $0.49^{a}$ & $0.47^{\mathrm{a}}$ & $0.38^{\mathrm{b}}$ & $0.39^{b}$ & $0.38^{\mathrm{b}}$ & 0.033 & 0.004 & 0.001 & 0.087 \\
\hline $15: 1$ cis -10 & 0.00 & 0.00 & 0.01 & 0.00 & 0.01 & 0.00 & 0.002 & 0.143 & 0.124 & 0.098 \\
\hline $16: 0$ & 34.05 & 31.61 & 32.88 & 27.44 & 27.80 & 28.26 & 1.422 & 0.001 & 0.000 & 0.263 \\
\hline $16: 1$ cis $-7+18: 1$ trans & $0.18^{\mathrm{b}}$ & $0.18^{\mathrm{b}}$ & $0.16^{\mathrm{b}}$ & $0.24^{\mathrm{a}}$ & $0.23^{\mathrm{a}}$ & $0.22^{\mathrm{a}}$ & 0.018 & 0.002 & 0.000 & 0.735 \\
\hline $16: 1$ cis-9 & 2.04 & 1.87 & 1.94 & 1.61 & 1.69 & 1.65 & 0.274 & 0.367 & 0.042 & 0.740 \\
\hline $16: 0$ iso & 0.01 & 0.01 & 0.01 & 0.02 & 0.01 & 0.02 & 0.004 & 0.399 & 0.175 & 0.725 \\
\hline $16: 1$ cis-11 & 0.01 & 0.01 & 0.01 & 0.01 & 0.01 & 0.01 & 0.003 & 0.920 & 0.589 & 0.625 \\
\hline 16:0 anteiso & $0.37^{\mathrm{c}}$ & $0.42^{a b}$ & $0.39 \mathrm{bc}$ & $0.43^{\mathrm{a}}$ & $0.43^{\mathrm{a}}$ & $0.41^{\mathrm{ab}}$ & 0.021 & 0.021 & 0.006 & 0.144 \\
\hline $17: 0$ & 0.48 & 0.51 & 0.51 & 0.51 & 0.51 & 0.51 & 0.020 & 0.469 & 0.243 & 0.356 \\
\hline $17: 1$ cis-9 & 0.17 & 0.17 & 0.17 & 0.17 & 0.17 & 0.17 & 0.019 & 0.994 & 0.605 & 0.986 \\
\hline
\end{tabular}


Table 4. Cont.

\begin{tabular}{|c|c|c|c|c|c|c|c|c|c|c|}
\hline Fatty Acid & IR & FB & FP & $\mathrm{IR}+\mathrm{G}$ & FB + G & $F P+G$ & SD & D & G & $\mathbf{D} * \mathbf{G}$ \\
\hline 18:0 & $6.71^{b}$ & $8.22^{a}$ & $7.63^{a b}$ & $8.89^{a}$ & $8.17^{\mathrm{a}}$ & $8.11^{a b}$ & 0.778 & 0.090 & 0.039 & 0.077 \\
\hline $18: 1$ trans $-4+18: 1$ trans -5 & 0.01 & 0.01 & 0.01 & 0.01 & 0.01 & 0.01 & 0.002 & 0.771 & 0.289 & 0.669 \\
\hline $18: 1$ trans $-6+18: 1$ trans -9 & $0.40^{b}$ & $0.49^{\mathrm{a}}$ & $0.44^{\mathrm{ab}}$ & $0.45^{\mathrm{ab}}$ & $0.48^{\mathrm{a}}$ & $0.45^{\mathrm{ab}}$ & 0.041 & 0.222 & 0.377 & 0.421 \\
\hline 18:1 trans -10 & 0.28 & 0.31 & 0.27 & 0.29 & 0.29 & 0.27 & 0.029 & 0.540 & 0.962 & 0.630 \\
\hline 18:1 trans- 11 & $0.86^{\mathrm{d}}$ & $1.12^{\mathrm{c}}$ & $0.93^{\mathrm{cd}}$ & $3.22^{b}$ & $3.42^{\mathrm{ab}}$ & $3.54^{\mathrm{a}}$ & 0.138 & 0.000 & 0.000 & 0.158 \\
\hline 18:1 trans -12 & $0.25^{\mathrm{c}}$ & $0.32^{a}$ & $0.25^{c}$ & $0.27^{a b c}$ & $0.30 \mathrm{ab}$ & $0.27^{b c}$ & 0.027 & 0.050 & 0.686 & 0.472 \\
\hline $18: 1$ trans $-13+18: 1$ trans -14 & 0.32 & 0.35 & 0.33 & 0.33 & 0.34 & 0.28 & 0.038 & 0.386 & 0.338 & 0.502 \\
\hline $18: 1 \mathrm{n} 9$ cis -9 & $15.80^{d}$ & $17.29 \mathrm{bc}$ & $16.79 \mathrm{~cd}$ & $18.28^{a b}$ & $18.42^{\mathrm{a}}$ & $17.87^{a b}$ & 0.590 & 0.002 & 0.000 & 0.114 \\
\hline $18: 1$ cis $-10+18: 1$ trans -15 & 0.22 & 0.24 & 0.22 & 0.23 & 0.25 & 0.24 & 0.029 & 0.856 & 0.399 & 0.885 \\
\hline $18: 1 n 7$ cis -11 & 0.56 & 0.55 & 0.50 & 0.58 & 0.56 & 0.53 & 0.052 & 0.577 & 0.440 & 0.951 \\
\hline $18: 1$ cis-12 & $0.22^{a b}$ & $0.26^{\mathrm{a}}$ & $0.26^{\mathrm{a}}$ & $0.16^{\mathrm{b}}$ & $0.18^{b}$ & $0.16^{\mathrm{b}}$ & 0.032 & 0.009 & 0.001 & 0.598 \\
\hline 18:1 trans- 16 & $0.21^{\mathrm{c}}$ & $0.30^{b}$ & $0.24^{\mathrm{c}}$ & $0.34^{\mathrm{ab}}$ & $0.37^{\mathrm{a}}$ & $0.31^{b}$ & 0.025 & 0.000 & 0.000 & 0.130 \\
\hline $18: 2$ trans -9, trans -12 & $0.04^{b}$ & $0.05^{b}$ & $0.04^{b}$ & $0.07^{\mathrm{a}}$ & $0.08^{a}$ & $0.08^{a}$ & 0.009 & 0.001 & 0.000 & 0.934 \\
\hline $18: 2$ cis- 9, cis- 12 & 1.65 & 1.83 & 1.81 & 1.49 & 1.51 & 1.54 & 0.176 & 0.129 & 0.012 & 0.729 \\
\hline c9.t11-CLA & $0.54^{\mathrm{c}}$ & $0.60^{\mathrm{c}}$ & $0.52^{\mathrm{c}}$ & $1.48^{\mathrm{b}}$ & $1.67^{\mathrm{a}}$ & $1.67^{\mathrm{ab}}$ & 0.100 & 0.000 & 0.000 & 0.236 \\
\hline Other CLA & $0.17^{c}$ & $0.22^{\mathrm{a}}$ & $0.19^{b}$ & $0.19^{b}$ & $0.23^{\mathrm{a}}$ & $0.19^{b}$ & 0.013 & 0.001 & 0.065 & 0.297 \\
\hline CLA trans, trans & $0.03^{b}$ & $0.03^{b}$ & $0.03^{b}$ & $0.08^{\mathrm{a}}$ & $0.09^{\mathrm{a}}$ & $0.07^{\mathrm{a}}$ & 0.011 & 0.000 & 0.000 & 0.311 \\
\hline $18: 3(\mathrm{n} 3)$ & $0.35^{\mathrm{b}}$ & $0.37^{b}$ & $0.34^{\mathrm{b}}$ & $0.56^{\mathrm{a}}$ & $0.56^{\mathrm{a}}$ & $0.56^{\mathrm{a}}$ & 0.051 & 0.000 & 0.000 & 0.830 \\
\hline 18:3 (n6) & 0.04 & 0.04 & 0.05 & 0.04 & 0.04 & 0.04 & 0.006 & 0.476 & 0.111 & 0.916 \\
\hline $20: 0$ & 0.16 & 0.25 & 0.21 & 0.22 & 0.16 & 0.15 & 0.065 & 0.403 & 0.360 & 0.176 \\
\hline $20: 1$ cis-9 & $0.00^{\mathrm{c}}$ & $0.01 \mathrm{bc}$ & $0.00^{\mathrm{c}}$ & $0.02^{a b}$ & $0.02^{\mathrm{a}}$ & $0.02^{\mathrm{a}}$ & 0.005 & 0.001 & 0.000 & 0.831 \\
\hline $20: 1 n 9$ cis -11 & $0.03^{b}$ & $0.05^{\mathrm{ab}}$ & $0.03^{b}$ & $0.04^{\mathrm{ab}}$ & $0.06^{\mathrm{a}}$ & $0.04^{b}$ & 0.011 & 0.031 & 0.016 & 0.847 \\
\hline $20: 3$ & $0.26^{\mathrm{a}}$ & $0.24^{\mathrm{a}}$ & $0.26 \mathrm{a}$ & $0.19^{b}$ & $0.17^{b}$ & $0.17^{b}$ & 0.015 & 0.000 & 0.000 & 0.636 \\
\hline $20: 5$ & 0.01 & 0.01 & 0.01 & 0.01 & 0.01 & 0.01 & 0.003 & 0.888 & 0.649 & 0.881 \\
\hline $20: 2$ & 0.02 & 0.03 & 0.02 & 0.02 & 0.02 & 0.02 & 0.005 & 0.398 & 0.264 & 0.532 \\
\hline $20: 3$ & $0.15^{\mathrm{a}}$ & $0.15^{\mathrm{a}}$ & $0.15^{\mathrm{a}}$ & $0.10^{b}$ & $0.10^{\mathrm{b}}$ & $0.09^{b}$ & 0.018 & 0.002 & 0.000 & 0.717 \\
\hline $20: 4$ & $0.02^{a b}$ & $0.03^{\mathrm{a}}$ & $0.02^{b}$ & $0.02^{b}$ & $0.02^{b}$ & $0.02^{b}$ & 0.004 & 0.044 & 0.048 & 0.163 \\
\hline 21:0 & 0.05 & 0.05 & 0.05 & 0.06 & 0.05 & 0.05 & 0.005 & 0.203 & 0.405 & 0.051 \\
\hline $22: 0$ & $0.03^{\mathrm{d}}$ & $0.05^{b}$ & $0.05^{\mathrm{c}}$ & $0.06^{\mathrm{a}}$ & $0.06^{\mathrm{a}}$ & $0.06^{\mathrm{b}}$ & 0.003 & 0.000 & 0.000 & 0.000 \\
\hline $22: 5$ & 0.09 & 0.08 & 0.10 & 0.10 & 0.09 & 0.09 & 0.012 & 0.644 & 0.842 & 0.432 \\
\hline $22: 6$ & 0.01 & 0.01 & 0.01 & 0.01 & 0.01 & 0.01 & 0.006 & 0.813 & 0.905 & 0.876 \\
\hline $22: 2$ & $0.05^{b c}$ & $0.04^{\mathrm{c}}$ & $0.04^{\mathrm{c}}$ & $0.07^{\mathrm{a}}$ & $0.06^{\mathrm{ab}}$ & $0.07^{\mathrm{a}}$ & 0.009 & 0.004 & 0.000 & 0.607 \\
\hline $23: 0$ & $0.03^{c}$ & $0.03^{a b c}$ & $0.03^{b c}$ & $0.04^{\mathrm{abc}}$ & $0.04^{\mathrm{a}}$ & $0.04^{\mathrm{ab}}$ & 0.005 & 0.041 & 0.005 & 0.979 \\
\hline $24: 0$ & 0.04 & 0.05 & 0.05 & 0.05 & 0.05 & 0.04 & 0.009 & 0.225 & 0.530 & 0.172 \\
\hline $24: 1$ & 0.01 & 0.01 & 0.01 & 0.01 & 0.01 & 0.01 & 0.004 & 0.777 & 0.852 & 0.433 \\
\hline$\sum \mathrm{SFA}^{1}$ & $71.05^{\mathrm{a}}$ & $68.80^{\mathrm{b}}$ & $69.83^{a b}$ & $65.29^{c}$ & $64.35^{c}$ & $65.31^{\mathrm{c}}$ & 1.128 & 0.000 & 0.000 & 0.552 \\
\hline$\sum \mathrm{BFA}^{2}$ & $1.97^{b}$ & 2.17 & $2.09 \mathrm{ab}$ & $2.21^{\mathrm{a}}$ & $2.24^{\mathrm{a}}$ & $2.16^{\mathrm{ab}}$ & 0.098 & 0.073 & 0.023 & 0.290 \\
\hline$\sum$ MUFA $^{3}$ & $23.53^{b}$ & $25.29 \mathrm{~b}$ & $24.48^{b}$ & $28.08^{a}$ & $28.76^{\mathrm{a}}$ & $27.90^{\mathrm{a}}$ & 0.937 & 0.000 & 0.000 & 0.527 \\
\hline$\sum$ MUFA cis & $20.76^{b}$ & $21.92^{a b}$ & $21.58^{a b}$ & $22.55^{\mathrm{a}}$ & $22.93^{a}$ & $22.19^{\mathrm{a}}$ & 0.719 & 0.048 & 0.007 & 0.390 \\
\hline$\sum$ MUFA trans & $2.37^{c}$ & $2.95^{\mathrm{b}}$ & $2.52^{b c}$ & $5.06^{\mathrm{a}}$ & $5.36^{\mathrm{a}}$ & $5.26^{\mathrm{a}}$ & 0.260 & 0.000 & 0.000 & 0.521 \\
\hline MUFA cis + trans & $0.40 \mathrm{bc}$ & $0.42^{a b c}$ & $0.38^{\mathrm{c}}$ & $0.47^{\mathrm{a}}$ & $0.47^{\mathrm{a}}$ & 0.46 & 0.034 & 0.037 & 0.002 & 0.816 \\
\hline$\sum$ PUFA $^{4}$ & $3.44^{b}$ & $3.74^{b}$ & $3.59^{b}$ & $4.43^{\mathrm{a}}$ & $4.65^{\mathrm{a}}$ & $4.63^{\mathrm{a}}$ & 0.249 & 0.000 & 0.000 & 0.915 \\
\hline$\Sigma \mathrm{CLA}^{5}$ & $0.74^{\mathrm{c}}$ & $0.85^{c}$ & $0.75^{c}$ & $1.76^{\mathrm{b}}$ & $1.99^{\mathrm{a}}$ & $1.93^{\mathrm{ab}}$ & 0.107 & 0.000 & 0.000 & 0.415 \\
\hline$\sum \mathrm{n} 6$ & $1.98^{a b}$ & $2.17^{\mathrm{a}}$ & $2.13^{a b}$ & $1.81^{\mathrm{b}}$ & $1.81^{\mathrm{b}}$ & $1.86^{\mathrm{ab}}$ & 0.180 & 0.112 & 0.010 & 0.682 \\
\hline$\sum \mathrm{n} 3$ & $0.72^{b c}$ & $0.71^{\mathrm{c}}$ & $0.71^{\mathrm{c}}$ & $0.86^{\mathrm{a}}$ & $0.84^{\mathrm{ab}}$ & $0.84^{\mathrm{ab}}$ & 0.060 & 0.023 & 0.001 & 0.990 \\
\hline PUFA:SFA ratio & $0.05^{b}$ & $0.05^{b}$ & $0.05^{b}$ & $0.07^{\mathrm{a}}$ & $0.07^{\mathrm{a}}$ & $0.07^{\mathrm{a}}$ & 0.004 & 0.000 & 0.000 & 0.956 \\
\hline n6:n3 ratio & $2.74^{\mathrm{a}}$ & $3.05^{\mathrm{a}}$ & $2.99^{a}$ & $2.13^{b}$ & $2.16^{\mathrm{b}}$ & $2.22^{b}$ & 0.186 & 0.000 & 0.000 & 0.450 \\
\hline UFA:SFA ratio & $0.38^{b}$ & $0.42^{b}$ & $0.40^{b}$ & $0.50^{\mathrm{a}}$ & $0.52^{\mathrm{a}}$ & $0.50^{\mathrm{a}}$ & 0.023 & 0.000 & 0.000 & 0.652 \\
\hline 18:1 trans-11:trans-10 ratio & $3.15^{c}$ & $3.66^{c}$ & $3.36^{c}$ & $11.01^{\mathrm{b}}$ & $11.65^{b}$ & $13.26^{\mathrm{a}}$ & 0.661 & 0.000 & 0.000 & 0.040 \\
\hline
\end{tabular}

${ }^{1}$ SFA: saturated fatty acids; ${ }^{2}$ BFA: branched fatty acids; ${ }^{3}$ MUFA: monounsaturated fatty acids; ${ }^{4}$ PUFA: polyunsaturated fatty acids; ${ }^{5}$ CLA: Conjugated linoleic acid. ${ }^{a}$ b, $c$ : Means in a row with different superscripts differ among treatments.

The content of fat-soluble antioxidants according to the feeding system is shown in Table 5. No significant differences were observed in vitamin A (retinol) due to the type of feeding system. The levels of vitamin E ( $\gamma$-tocopherol) differed between type of total mixed rations and feeding management $(p<0.001)$. The levels in IR diets were lower than with both legumes and they were higher in indoor cows than in grazing ones. The lutein content was highest in FB than in the other diets and it reached higher values in grazing cows than in indoor ones. The levels in the other diets depended on the feeding strategy, so FP was higher than IR in indoor animals whereas the contrary was observed in grazing 
ones. The levels of $\beta$-cryptoxanthin differed between silage diets $(p<0.01)$, being highest in FB compared to IR and FP, and they were also higher in grazing cows than in indoor ones $(p<0.01)$. Although there were no differences in carotene concentration between treatments, a higher proportion $(p<0.05)$ was observed in grazing cows for carotenes.

Table 5. Fat-soluble antioxidants composition $(\mu \mathrm{g} / \mathrm{L})$ of milk according to the type of silage (D) included in the total mixed rations based on Italian ryegrass silage (IR), faba bean silage (FB), and field pea silage (FP), with or without grazing (G).

\begin{tabular}{|c|c|c|c|c|c|c|c|c|c|c|}
\hline Antioxidant & IR & FB & FP & $\mathrm{IR}+\mathrm{G}$ & $\mathbf{F B}+\mathrm{G}$ & $\mathbf{F P}+\mathrm{G}$ & SD & D & G & $\mathrm{D} * \mathrm{G}$ \\
\hline Retinol & 852 & 747 & 893 & 771 & 721 & 827 & 233.3 & 0.698 & 0.611 & 0.978 \\
\hline$\alpha$-Tocopherol & 1005 & 1171 & 1181 & 1372 & 1412 & 1645 & 303.0 & 0.231 & 0.031 & 0.820 \\
\hline$\gamma$-Tocopherol & $89.6^{\mathrm{bc}}$ & $99.0^{\mathrm{ab}}$ & $128.7^{\mathrm{a}}$ & $59.5^{\mathrm{d}}$ & $66.9^{\mathrm{cd}}$ & $61.4^{\mathrm{cd}}$ & 16.30 & 0.003 & 0.000 & 0.135 \\
\hline Lutein & $7.67^{b}$ & $11.09^{b}$ & $8.53^{\mathrm{b}}$ & $25.72^{\mathrm{a}}$ & $30.39^{a}$ & $21.48^{a b}$ & 7.449 & 0.014 & 0.001 & 0.744 \\
\hline Zeaxanthin & 0.71 & 0.76 & 0.57 & 1.84 & 1.67 & 1.76 & 0.795 & 0.227 & 0.017 & 0.948 \\
\hline$\beta$-Cryptoxanthin & $1.83^{\mathrm{b}}$ & $1.51^{b}$ & $1.39^{b}$ & $3.09^{\mathrm{a}}$ & $3.55^{\mathrm{a}}$ & $3.33^{\mathrm{a}}$ & 0.583 & 0.002 & 0.083 & 0.480 \\
\hline All-trans- $\beta$-Carotene & 148.5 & 149.6 & 119.4 & 217.5 & 242.0 & 245.0 & 69.49 & 0.194 & 0.015 & 0.782 \\
\hline 9-cis- $\beta$-Carotene & $0.92^{b}$ & $1.08^{b}$ & $0.57^{b}$ & $1.35^{\mathrm{ab}}$ & $2.03^{a b}$ & $2.72^{a}$ & 0.831 & 0.082 & 0.013 & 0.233 \\
\hline 13-cis- $\beta$-Carotene & 3.30 & 3.90 & 2.38 & 6.22 & 6.75 & 7.55 & 2.635 & 0.181 & 0.015 & 0.696 \\
\hline
\end{tabular}

a, b,c, d: Means in a row with different superscripts differ among treatments.

\section{Discussion}

Europe is highly dependent on a foreign protein supply because there is a deficit of high-quality protein forages homegrown for livestock. Legumes can be an alternative to reduce the inputs of farm, especially nitrogen fertilizers and protein supplements, because of their nitrogen fixation ability and high concentration of protein [11]. Faba bean and field pea are legumes that offer the possibility of increasing local protein self-sufficiency in areas where the possibilities of other protein crops are limited [24]. Both legumes can be competitive homegrown crops since they have comparable yields to Italian ryegrass under local conditions $[25,26]$.

Different studies point out to a higher potential for dry matter intake of legume silages and greater in milk production than grass silages [27]. These differences have been related to a faster fiber digestion rate in the rumen and an improvement in the balance between amino acids and metabolizable energy in the absorbed nutrients [28], since legumes have a lower concentration of neutral detergent fiber and a higher rate of degradation of detergent neutral fiber and lignin than grasses [29]. Some rumen fermentation studies have shown that the differences result in lower filling and a higher rate of rumen passage, which explains a higher intake capacity in legumes than in grasses [30]. Other studies reported a significant reduction in the voluntary intake of rations based on legumes in comparison to rations based on Italian ryegrass silage [31]. This fact was attributed to the tannins of legume blooms and seeds. However, the tannin concentration decreased through the silage process, and it was also diluted in the total mixed ration with the inclusion of more ingredients [32], promoting no significant differences in dry matter intake among diets. In the present study, no differences were observed in the dry matter intake nor milk production between total mixed rations including both legume silages or Italian ryegrass silage. However, the dry matter intake was slightly higher in treatments with grazing, as well as a trend towards higher milk production. However, FB treatment had the highest dry matter intake due to a large grass intake, but this was not reflected in the milk yield. No explanation for these abnormal results were found.

In this experiment, protein and urea contents decreased with grazing. High amounts of easily fermentable substances, such as starch and soluble sugars, increased volatile fatty acid concentrations in the rumen and decreased rumen $\mathrm{pH}$, negatively affecting microbial activity [33]. The higher starch content in rations based in legume silage may have increased starch digestion in the small intestine, consequently increasing glucose absorption in the small intestine. A high concentration of glucose in blood favors the protein synthesis [34]. Similarly, there is a positive correlation between the concentration 
of propionic acid in rumen and protein in milk [35] because it favors the availability of amino acids. The legume silage inclusion increased the urea content in milk, especially in housing animals and with TMR based on field pea in both managements. The urea content in milk reflects dietary protein intake and ruminal metabolism [36]. In this experiment, the high levels of urea content in the milk from dairy cows feeding TMR based on legume silages, especially in the FP treatment, could be attributed to an excess of soluble protein in the diet or to an inefficient use of protein. The protein and energy ratio of the diet or the non-degradable and degradable protein ratio in the rumen can affect the urea content in milk [37]. In a similar work [31], the milk from dairy cows fed diets based on faba bean had higher urea concentrations than those fed with diets based on Italian ryegrass silage. The high level of urea in the milk may also be related to the use of legume silages that have higher ammoniacal nitrogen contents. The protein of field pea is subject to extensive degradation to non-protein nitrogen [38], in that it will be rapidly degraded to ammonia in the rumen and, if not captured as microbial protein, will end up largely as urea nitrogen in milk and in urine. A large amount of urinary nitrogen is excreted into the environment resulting from highly degradable protein [39]. Urea accounts for the most part of the nitrogen in the urine of cattle.

The fat content of the milk in our experiment was not affected by the different treatments based on legume silage or ryegrass silage, both with and without grazing. Lower fat content has been observed in milk from dairy cows feeding diets based in legume silage than based in grass silage [27], which may be due to fatty acid isomers produced during rumen biohydrogenation. Some intermediate fatty acids in the biohydrogenation pathway inhibit milk fat synthesis [40] due to high concentrations of these intermediate products in the milk from cows feeding on legumes [41]. Long-chain fatty acids inhibit the ex novo synthesis of milk fatty acids and therefore contribute to reducing the fat content of milk.

The legumes have lower concentrations of C18:3 n-3 and higher concentrations of the C18:2 n- 6 and C16:0 fatty acids than the grasses [42], although a great variation within the families Poaceae and Fabaceae is also observed. These results are closely related to the results obtained in the plots used for grazing in this study, where linolenic acid constituted up to $49 \%$ of the total FA. The differences in total mixed rations in this experiment are reflected in the fatty acid profiles of milk, because the concentration of fatty acids in milk are closely related to the diet provided to animals [43]. The results obtained show that fresh forage is the main source of polyunsaturated fatty acids in the diet of ruminants, according to others' studies [44-46]. In the fatty acid profile of milk, strong differences were observed attending to the type of silage in the diet and to the management with and without grazing. A higher concentration of saturated fatty acids was observed in treatments without grazing, where palmitic acid had a lower concentration in treatment without grazing, whereas oleic acid was higher. The higher concentrations of monounsaturated fatty acids and polyunsaturated fatty acids in the milk produced with FB and FP in this study is accordant with the increase in the proportion of these fatty acids in the milk of cows feeding on red clover silage compared to grass silage [41]. Those results were associated with concomitant reductions from 10:0 to 16:0 concentrations. Rumen biohydrogenation of polyunsaturated fatty acids may be reduced in legume diets due to reduced lipolysis mediated by the action of the enzyme polyphenol oxidase present in plants, a prerequisite for microbial hydrogenation of the rumen of unsaturated fatty acids [47], which may explain the improved levels of polyunsaturated fatty acids in the milk of cows fed legume silages. In the present study, it was observed that when Italian ryegrass silage is replaced on the TMR by legume silage, especially with faba bean, milk fat has a higher proportion of unsaturated fatty acids. In addition, grazing influences directly on the composition of milk, improving its quality by increasing the proportion of total CLA, in particular rumenic acid, as well as the ratio $18: 1$ trans-11/18:1 trans-10, thus providing a more unsaturated fatty acid profile for the consumer. In a simulation study conducted under New Zealand conditions was concluded that the high concentration of unsaturated fatty acids in milk fat is associated with lower yield and percentages of fat and protein per 
cow [48]. However, in the present study, the milk from cows fed IR ration without grazing had the lowest concentration of unsaturated fatty acids, but it had only higher protein concentration than the other treatments while no differences were observed in milk yield nor fat concentration among treatments. The fresh forage is especially rich in linolenic acid, which is extensively biohydrogenated in the rumen to vaccenic acid (18:1 trans-11) that subsequently is desaturated to CLA in the mammary gland [45]. A low $n-6 / n-3$ ratio is indicative of a grass-based diet [45]. This fact is according with the results of this study, where the lowest $n-6 / n-3$ ratio correspond to milk produced with the grazing management.

The fresh forage contains fat-soluble vitamins and pro-vitamins with antioxidant properties, such as $\alpha$-tocopherol, $\beta$-carotene, and lutein [49], which can be transferred directly to milk [15]. In the present study, significant differences in vitamin E, lutein, and $\beta$-cryptoxanthin concentrations were observed due to grazing, according to the results reported by other authors of milk from cows feeding on fresh herbage [50]. Several studies have reported that the content of $\beta$-carotenes and fat-soluble vitamins are even four times higher in the milk from grazing cows than in the milk from cows feeding on total mixed rations or diets with a high proportion of concentrate [51]. However, there was no differences in retinol content of milk due to the type of feeding system. This fact could be due to the daily secretion of retinol to milk seeming not to be related to the milk or milk fat yield and being dependent on genetic variations [12].

\section{Conclusions}

Grazing cows produce milk with a more unsaturated fatty acid profile than housing cows. Grazing directly influences the composition of milk, improving its quality by decreasing the proportion of saturated fatty acids and increasing the content of unsaturated fatty acid and CLA, as well as with higher contents of lutein and $\beta$-cryptoxanthin. When Italian ryegrass silage is replaced with TMR by legume silage, milk fat has a higher proportion of unsaturated fatty acids, especially with the inclusion of faba bean silage in the ration. In conclusion, the use of total mixed ration based on faba bean silage in combination with grazing has proved a greater capacity to produce milk with high ratio of unsaturated and saturated fatty acids and high concentration of antioxidants. Therefore, the faba bean could be an alternative to Italian ryegrass to feed dairy cows to improve the food self-sufficiency of dairy farms.

Author Contributions: Conceptualization, F.V.; methodology, F.V. and A.M.-F.; software, S.D.L.T.-S. and F.V.; validation, F.V., A.M.-F. and L.J.R.; formal analysis, S.D.L.T.-S. and M.M.-M.; investigation, S.D.L.T.-S. and F.V.; resources, F.V., A.M.-F., L.J.R. and R.R.-G.; data curation, S.D.L.T.-S. and F.V.; writing — original draft preparation, S.D.L.T.-S.; writing—review and editing, F.V., R.R.-G. and M.M.-M.; visualization, S.D.L.T.-S. and F.V.; supervision, F.V. and L.J.R.; project administration, L.J.R.; funding acquisition, L.J.R. All authors have read and agreed to the published version of the manuscript.

Funding: This research was funded by the National Institute for Agricultural and Food Research and Technology (INIA, Spain) through project RTA2014-00086-C02, by the Principality of Asturias through PCTI IDI/2021/000102 (GRUPIN NySA) and co-financed with European Regional Development Fund (ERDF). S.D.L.T.-S. is recipient of a SENACYT-IFARHU, Panama, doctoral fellowship.

Institutional Review Board Statement: The study has been evaluated in accordance with current Spanish and European legislation (RD 53/2013, EU directive 2010/63/UE) and has been considered outside the scope of application, although the questions referring welfare and housing conditions, have been taken into consideration.

Informed Consent Statement: Not applicable.

Data Availability Statement: All data used to support the findings of this study are included within the article. 
Acknowledgments: The authors would like to thank the staff of SERIDA for all the technical assistance and the consolidated research group Nutrición y Sanidad Animal (NySA) for their participation and collaboration.

Conflicts of Interest: The authors declare no conflict of interest.

\section{References}

1. Makkar, H.P. Animal nutrition in a 360-degree view and a framework for future R\&D work: Towards sustainable livestock production. Anim. Prod. Sci. 2016, 56, 1561-1568. [CrossRef]

2. Lamminen, M.; Halmemies-Beauchet-Filleau, A.; Kokkonen, T.; Vanhatalo, A.; Jaakkola, S. The effect of partial substitution of rapeseed meal and faba beans by Spirulina platensis microalgae on milk production, nitrogen utilization, and amino acid metabolism of lactating dairy cows. J. Dairy Sci. 2019, 102, 7102-7117. [CrossRef] [PubMed]

3. Elgersma, A.; Tamminga, S.; Ellen, G. Modifying milk composition through forage. Anim. Feed Sci. Technol. 2006, 131, 207-225. [CrossRef]

4. Elgersma, A.; Søegaard, K.; Jensen, S.K. Fatty acids, $\alpha$-tocopherol, $\beta$-carotene, and lutein contents in forage legumes, forbs, and a grass-clover mixture. J. Agric. Food Chem. 2013, 61, 11913-11920. [CrossRef]

5. Blagojević, M.; Đorđević, N.; Bora, D.; Marković, J.; Vasić, T.; Milenković, J.; Petrović, M. Determination of green forage and silage protein degradability of some pea (Pisum sativum L.) + oat (Avena sativa L.) mixtures grown in Serbia. J. Agric. Sci. 2017, 23, 415-422. [CrossRef]

6. Lehuger, S.; Gabrielle, B.; Gagnaire, N. Environmental impact of the substitution of imported soybean meal with locally-produced rapeseed meal in dairy cow feed. J. Clean. Prod. 2009, 17, 616-624. [CrossRef]

7. European Commission. Report from the Commission to the Council and the European Parliament on the Development of Plant Proteins in the European Union. Available online: https://ec.europa.eu/info/sites/default/files/food-farming-fisheries/plants_ and_plant_products / documents / report-plant-proteins-com2018-757-final_en.pdf (accessed on 29 September 2021).

8. Luscher, A.; Mueller-Harvey, I.; Soussana, J.F.; Rees, R.M.; Peyraud, J.L. Potential of legume-based grassland-livestock systems in Europe: A review. Grass Forage Sci. 2014, 69, 206-228. [CrossRef]

9. Peeters, A.; Parente, G.; Le Gall, A. Temperate legumes: Key-species for sustainable temperate mixtures. Grassl. Sci. Eur. 2006, 11, 205-220.

10. Borreani, G.; Chion, A.R.; Colombini, S.; Odoardi, M.; Paoletti, R.; Tabacco, E. Fermentative profiles of field pea (Pisum sativum), faba bean (Vicia faba) and white lupin (Lupinus albus) silages as affected by wilting and inoculation. Anim. Feed Sci. Technol. 2009, 151, 316-323. [CrossRef]

11. Preissel, S.; Reckling, M.; Schläfke, N.; Zander, P. Magnitude and farm-economic value of grain legume pre-crop benefits in Europe: A review. Field Crop. Res. 2015, 175, 64-79. [CrossRef]

12. Jensen, E.S.; Peoples, M.B.; Hauggaard-Nielsen, H. Faba bean in cropping systems. Field Crop. Res. 2010, 115, 203-216. [CrossRef]

13. Martínez-Fernández, A.; Soldado, A.; Vicente, F.; Martínez, A.; de la Roza-Delgado, B. Wilting and inoculation of Lactobacillus buchneri on intercropped triticale-fava silage: Effects on nutritive, fermentative and aerobic stability characteristics. Agric. Food Sci. 2010, 19, 302-312. [CrossRef]

14. Martínez-Fernández, A.; Soldado, A.; de la Roza-Delgado, B.; Vicente, F.; González-Arrojo, M.A.; Argamentería, A. Modelling a quantitative ensilability index adapted to forages from wet temperate areas. Span. J. Agric. Res. 2016, 11, 455-462. [CrossRef]

15. Morand-Fehr, P.; Fedele, V.; Decandia, M.; Le Frileux, Y. Influence of farming and feeding systems on composition and quality of goat and sheep milk. Small Rumin. Res. 2007, 68, 20-34. [CrossRef]

16. Noziere, P.; Graulet, B.; Lucas, A.; Martin, B.; Grolier, P.; Doreau, M. Carotenoids for ruminants: From forages to dairy products. Anim. Feed Sci. Technol. 2006, 131, 418-450. [CrossRef]

17. Jensen, S.K.; Johannsen, A.K.B.; Hermansen, J.E. Quantitative secretion and maximal secretion capacity of retinol, beta-carotene and alpha-tocopherol into cows' milk. J. Dairy Res. 1999, 66, 511-522. [CrossRef]

18. NRC. Nutrient Requirements of Dairy Cattle, 7th ed.; National Academy Press: Washington, DC, USA, 2001.

19. Macoon, B.; Sollenberger, L.E.; Moore, J.E.; Staples, C.R.; Fike, J.H.; Portier, K.M. Comparison of three techniques for estimating the forage intake of lactating dairy cows on pasture. J. Anim. Sci. 2003, 81, 2357-2366. [CrossRef] [PubMed]

20. Sukhija, P.S.; Palmquist, D.L. Rapid method for determination of total fatty acid content and composition of feedstuffs and feces. J. Agric. Food Chem. 1988, 36, 1202-1206. [CrossRef]

21. Chauveau-Duriot, B.; Doreau, M.; Noziere, P.; Graulet, B. Simultaneous quantification of carotenoids, retinol, and tocopherols in forages, bovine plasma, and milk: Validation of a novel UPLC method. Anal. Bioanal. Chem. 2010, 397, 777-790. [CrossRef]

22. Gentili, A.; Caretti, F.; Bellante, S.; Ventura, S.; Canepari, S.; Curini, R. Comprehensive profiling of carotenoids and fat-soluble vitamins in milk from different animal species by LC-DAD-MS/MS hyphenation. J. Agric. Food Chem. 2013, 61, 1628-1639. [CrossRef]

23. R Core Team. R: A Language and Environment for Statistical Computing. In R Foundation for Statistical Computing; R Core Team: Vienna, Austria, 2018; Available online: https:/ / www.R-project.org/ (accessed on 16 July 2020).

24. Rinne, M.; Leppä, M.M.; Kuoppala, K.; Koivunen, E.; Kahala, M.; Jalava, T.; Salminen, J.P.; Manni, K. Fermentation quality of ensiled crimped faba beans using different additives with special attention to changes in bioactive compounds. Anim. Feed Sci. Technol. 2020, 235, 114497. [CrossRef] 
25. Baizán, S.; Vicente, F.; Oliveira, J.A.; Afif-Khouri, E.; Martínez-Fernández, A. Effect of replacing conventional Italian ryegrass by organic nitrogen source systems on chemical soil properties. Span. J. Agric. Res. 2021, 18, e1105. [CrossRef]

26. Monti, M.; Pellicanò, A.; Santonoceto, C.; Preiti, G.; Pristeri, A. Yield components and nitrogen use in cereal-pea intercrops in Mediterranean environment. Field Crop Res. 2016, 196, 379-388. [CrossRef]

27. Steinshamn, H. Effect of forage legumes on feed intake, milk production and milk quality-a review. Anim. Sci. Pap. Rep. 2010, 28, 195-206.

28. Ramin, M.; Höjer, A.; Hetta, M. The effects of legume seeds on the lactation performance of dairy cows fed grass silage-based diets. Agric. Food Sci. 2017, 26, 129-137. [CrossRef]

29. Weisbjerg, M.R.; Søegaard, K. Feeding value of legumes and grasses at different harvest times. Grassl. Sci. Eur. 2008, 13, 513-515.

30. Kuoppala, K.; Ahvenjärvi, S.; Rinne, M.; Vanhatalo, A. Effects of feeding grass or red clover silage cut at two maturity stages in dairy cows. 2. Dry matter intake and cell wall digestion kinetics. J. Dairy Sci. 2009, 92, 5634-5644. [CrossRef]

31. Jiménez-Calderón, J.D.; Martínez-Fernández, A.; Soldado, A.; González, A.; Vicente, F. Faba bean-rapeseed silage as substitute for Italian ryegrass silage: Effects on performance and milk quality of grazing dairy cows. Anim. Prod. Sci. 2020, 60, 913-922. [CrossRef]

32. Baizán, S.; Vicente, F.; Barhoumi, N.; Feito, I.; Rodríguez, L.; Martínez-Fernández, A. Effect of faba bean silage in dairy cow diets on voluntary intake, milk production and composition of milk. ITEA 2018, 114, 353-367. [CrossRef]

33. Mould, F.L.; Ørskov, E.R.; Mann, S.O. Associative effects of mixed feeds. I. Effects of type and level of supplementation and the influence of the rumen fluid $\mathrm{pH}$ on cellulolysis in vivo and dry matter digestion of various roughages. Anim. Feed Sci. Technol. 1983, 10, 15-30. [CrossRef]

34. Puhakka, L.; Jaakkola, S.; Simpura, I.; Kokkonen, T.; Vanhatalo, A. Effects of replacing rapeseed meal with fava bean at 2 concentrate crude protein levels on feed intake, nutrient digestion, and milk production in cows fed grass silage-based diets. $J$. Dairy Sci. 2016, 99, 7993-8006. [CrossRef] [PubMed]

35. Rook, J.A.F. The role of carbohydrate metabolism in the regulation of milk production. Proc. Nutr. Soc. 1979, 38, 309-314. [CrossRef] [PubMed]

36. Wittwer, F.G.; Gallardo, P.; Reyes, J.; Opitz, H. Bulk milk urea concentrations and their relationship with cow fertility in grazing dairy herds in Southern Chile. Prev. Vet. Med. 1999, 38, 159-166. [CrossRef]

37. Baker, L.D.; Ferguson, J.D.; Chalupa, W. Responses in urea and true protein of milk to different protein feeding schemes for dairy cows. J. Dairy Sci. 1995, 78, 2424-2434. [CrossRef]

38. McDonald, P.; Henderson, A.R.; Heron, S.J.E. The Biochemistry of Silage, 2nd ed.; Chalcombe Publications: Marlow, UK, 1991.

39. Kebreab, E.; France, J.; Beever, D.; Castillo, A. Nitrogen pollution by dairy cows and its mitigation by dietary manipulation. Nutr. Cycl. Agroecosyst. 2001, 60, 275-285. [CrossRef]

40. Bauman, D.E.; Perfield, J.W.; Harvatine, K.J.; Baumgard, L.H. Regulation of fat synthesis by conjugated linoleic acid: Lactation and the ruminant model. J. Nutr. 2008, 138, 403-409. [CrossRef]

41. Vanhatalo, A.; Kuoppala, K.; Toivonen, V.; Shingfield, K.J. Effects of forage species and stage of maturity on bovine milk fatty acid composition. Eur. J. Lipid Sci. Tech. 2007, 108, 856-867. [CrossRef]

42. Boufaïed, H.; Chouinard, P.Y.; Tremblay, G.F.; Petit, H.V.; Michaud, R.; Bélanger, G. Fatty acids in forages. I. Factors affecting concentrations. Can. J. Anim. Sci. 2003, 83, 501-511. [CrossRef]

43. Morales-Almaráz, E.; de la Roza-Delgado, B.; González, A.; Soldado, A.; Rodríguez, M.L.; Peláez, M.; Vicente, F. Effect of feeding system on unsaturated fatty acid level in milk of dairy cows. Renew. Agric. Food Syst. 2011, 26, 224-229. [CrossRef]

44. Khan, N.A.; Cone, J.W.; Fievez, V.; Hendriks, W.H. Causes of variation in fatty acid content and composition in grass and maize silages. Anim. Feed Sci. Technol. 2012, 174, 36-45. [CrossRef]

45. Elgersma, A. Grazing increases the unsaturated fatty acid concentration of milk from grass-fed cows: A review of the contributing factors, challenges and future perspectives. Eur. J. Lipid Sci. Tech. 2015, 117, 1345-1369. [CrossRef]

46. Magan, J.B.; O'Callaghan, T.F.; Kelly, A.L.; McCarthy, N.A. Compositional and functional properties of milk and dairy products derived from cows fed pasture or concentrate-based diets. Compr. Rev. Food Sci. Food Saf. 2021, 20, 2769-2800. [CrossRef]

47. Lee, M.R.F.; Harris, L.J.; Dewhurst, R.J.; Merry, R.J.; Scollan, N.D. The effect of clover silages on long chain fatty acid rumen transformations and digestion in beef steers. Anim. Sci. 2003, 76, 491-501. [CrossRef]

48. Silva-Villacorta, D.; Lopez-Villalobos, N.; Blair, H.T.; Hickson, R.E.; MacGibbon, A.K. Production and profitability of dairy farms producing milk with different concentrations of unsaturated fatty acids: A simulation study. N. Z. J. Agric. Res. 2017, 60, 32-44. [CrossRef]

49. Ballet, N.; Robert, J.C.; Williams, P.E.V. Vitamins in Forages. In Forage Evaluation in Ruminant Nutrition; Givens, D., Axford, R., Owenm, E., Eds.; CABI Publishing: Egham, UK, 2000; pp. 399-431.

50. Agabriel, C.; Cornu, A.; Journal, C.; Sibra, C.; Grolier, P.; Martin, B. Tanker milk variability according to farm feeding practices: Vitamins A and E, carotenoids, color, and terpenoids. J. Dairy Sci. 2007, 90, 4774-4896. [CrossRef] [PubMed]

51. Butler, G.; Nielsen, J.H.; Slots, T.; Seal, C.; Eyre, M.D.; Sanderson, R.; Leifert, C. Fatty acid and fat-soluble antioxidant concentrations in milk from high-and low-input conventional and organic systems: Seasonal variation. J. Sci. Food Agric. 2008, 88, 1431-1441. [CrossRef] 